\title{
Does the immigration issue divide the left's attitudes towards social welfare? A study on public support of social benefits and services in the Nordic countries
}

\author{
Laura Häkkilä and Timo Toikko \\ Department of Social Sciences, University of Eastern Finland, Kuopio, Finland
}

Study on public attitudes towards social benefits

\begin{abstract}
Purpose - The paper presents a study on whether citizens' immigration attitudes shape their attitudes towards social welfare in three Nordic countries.

Design/methodology/approach - The main analysis was performed using linear regression analysis. Data were retrieved from the eighth round of the European Social Survey (2016). The data cover the Finnish, Norwegian and Swedish respondents $(N=5,021)$.

Findings - The analyses indicate that citizens' immigration attitudes are associated with their social welfare attitudes. The more positive the attitudes towards immigration are, the more positive the attitudes toward social welfare will be. Further, people in the political Left have more positive attitudes towards social welfare compared to those in the political Right; but, the immigration issue is more divisive of the political Left's opinion than that of the Right.

Research limitations/implications - Public opinion research has its limitations because behind an individual's opinion there are many hidden factors. An individual may also have different opinions depending on the dimensions of the welfare state.

Social implications - If the immigration issue reduces the support for social welfare among the political Left, it may reduce the legitimacy of the Nordic social policy because the support of the political Left has traditionally been in favour of the universal principles of the welfare state.

Originality/value - The association of the immigration issue and social welfare attitudes has been broadly studied; but, the interaction of the immigration issue and political opinion on social welfare attitudes is less studied.
\end{abstract}

Keywords Social welfare attitudes, Immigration, Political opinion, Social policy, Social security,

European Social Survey

Paper type Research paper

\section{Introduction}

The Nordic countries are seen as examples of the nations of the universal social policy system (Anttonen and Sipilä, 2012) and social-democratic welfare regime (Esping-Andersen, 1990).

C Laura Häkkilä and Timo Toikko. Published by Emerald Publishing Limited. This article is published under the Creative Commons Attribution (CC BY 4.0) licence. Anyone may reproduce, distribute, translate and create derivative works of this article (for both commercial and non-commercial purposes), subject to full attribution to the original publication and authors. The full terms of this licence may be seen at http://creativecommons.org/licences/by/4.0/legalcode

Funding: There is no external funding source.

Author contribution: Laura Häkkilä, conceptualised and designed the study, carried out the initial analyses, drafted the initial manuscript, and revised the manuscript. Prof. Toikko critically reviewed the manuscript for important intellectual content. Both authors approved the final manuscript as submitted and agreed to be accountable for all aspects of the work.

Compliance with ethical standards: The Authors declare that they have no conflict of interest.

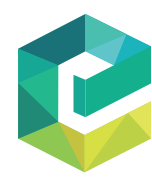

International Journal of Sociology and Social Polic Vol. 41 No. 13/14, 2021 
IJSSP

$41,13 / 14$

Citizens' support of the principles of universalism has maintained its stability through turbulent economic times in the beginning of 21st century (Rantanen et al., 2015; Ellingsæter et al., 2017; Scarpa and Schierup, 2018). In the big picture, the Nordic countries are still nations with a high level of income redistribution, which is the basis of the state-funded universal social policy (Cantante, 2020).

Many recent studies have shown that immigration is a significant issue which explains citizen's social welfare attitudes (e.g. Diermeier et al., 2020; Gugushvili et al., 2021). Schmidt-Catran and Spies (2019) showed that native-born populations become more reluctant to support welfare programmes when the proportion of foreigners at the regional level increases. They also found that native citizens turn to having more negative attitudes towards social welfare programmes when the immigration rate is increasing. Burgoon and Rooduijin (2021) write on the "Immigrationization of welfare policy" and emphasise that the attitudes towards immigration are associated with the support for the social welfare system. They found a negative connection between attitudes towards immigration and support for welfare redistribution.

In this study, we focus on three Nordic countries (Finland, Norway and Sweden), where the public support for the welfare state has traditionally been strong (e.g. Rantanen et al., 2015; Ellingsæter et al., 2017; Svallfors, 2011). We study the immigration issue in relation to the citizens' social welfare attitudes. Sweden has a long tradition with labour migration, inclusive of migration policy (Scarpa and Schierup, 2018), while Finland and Norway have been more homogenous countries, although Norway has had more labour migration compared to Finland. However, at least since the refugee crisis in 2015 [1], immigration has become a key issue associated with public policy in all three Nordic countries. From this perspective, we study whether the immigration issue plays a significant role in attitudes towards social welfare and, moreover, whether the effect of the immigration issue depends on socio-economic factors, such as citizens' education levels, political opinions and income levels. Our main interest is in the association of immigration attitudes and political opinions which, to our knowledge, have not been studied to date (cf. Breznau, 2018; Eger and Bohman, 2016).

\section{Theoretical background}

\subsection{Attitudes towards social welfare}

Welfare states have made different choices for securing citizens' well-being. These choices can be divided according to the questions regarding collective responsibility and individual responsibility. In some countries, the role of the public sector is central in securing citizens' well-being, but some other countries emphasise the individual's own responsibility towards their own well-being. The question of responsibility includes a discussion on the role of people who belong to the labour force and those who do not belong to the labour force (Esping-Andersen, 1990). Social political choices are strongly related to measures for helping dependents and poor people; hence, it is a question of deciding who are the deserving poor and who are the undeserving poor (van Oorschot, 2000; Mackenzie and Louth, 2020).

National social policy has an attitudinal basis (cf. Ervasti, 2012; Kumlin and Stadelmann-Steffen, 2014). To be effective, social policy must be accepted by the citizens it is meant to serve. It is assumed that individuals' social political attitudes can be deduced from long-term class interests (power resource theory), short-term self-interest (new politics theory) or internalised values and norms (culture theory) (Larsen, 2008). Referring to power resource theory (Korpi, 1983), it is assumed that the middle class have formed a kind of welfare coalition with the working class in the Nordic welfare states and an anti-welfare coalition with the upper class in the Liberal welfare states. Especially, the 
political Left has been supporting and defending the ideology of the Nordic welfare state (Nygård, 2006).

On the other hand, it is seen that citizens' social welfare attitudes are based on their self-interests. It is assumed that people support social welfare if it is within their own interests. According to interest theory, people whose income does not cover their basic needs are more likely to defend social welfare than people without economic difficulties (Davids and Gouws, 2013; van Oorschot and Halman, 2000). According to Pierson (2001), the "welfare clientele" (those who receive benefits) are big in the socio-democratic regime, moderate in the conservative regimes and small in the liberal regimes. Furthermore, scholars have emphasised the importance of "culture" or "dominant welfare state ideology" as an instrument which explains how citizens adopt a certain view towards the welfare state (Toikko et al., 2021; Blekesaune and Quadagno, 2003).

However, social welfare attitudes have been found to be multidimensional. People have different attitudes towards the different dimensions of the welfare state, such as the role of the state in different policy areas, its efficiency and its intended and unintended outcomes. People are positive about some of these dimensions, but they might be more critical about other dimensions (Roosma et al., 2014). Furthermore, it has been found that the relationship between social welfare attitudes and the dimensions differs between countries: Southern and Eastern Europeans have positive attitudes towards the role of the state but have more critical attitudes towards the welfare policy outcomes (Roosma et al., 2013). On the other hand, the welfare states are not as coherent in their social political systems as one may assume. Social policy of the Nordic countries includes the features of universal social policy, which is their trademark; but their social welfare system also includes means-tested measures; and its basis lies in the labour force, similar to all other welfare states.

\subsection{Socio-economic factors of social welfare attitudes}

Different factors may explain variations in social welfare attitude within countries. For instance, it has been assumed that women benefit relatively more from the social benefits and services of the welfare state than men, because women are still more outside of the labour force than men (Rantanen et al., 2015; Fernández and Jaime-Castillo, 2018; Kim and Yushin, 2018; Pederson and Shekha, 2018; Wulfgramm and Starke, 2017). Age is another significant factor for social welfare attitudes, but research results are contradictory. For instance, Blekesaune and Quadagno (2003) found that older people's attitudes to welfare are more positive than young people's attitudes, but the opposite pattern has also been found (Ervasti, 2001).

According to self-interest theory, citizens' income levels are a key factor related to the support of the welfare state. It is in the interests of low-income people to take a positive view of social benefits and services. They themselves can utilise social benefits and services in their current situation or in the future. For instance, unemployed people are accustomed to the support of social benefits more than employed people. Those in employment are also in favour of social benefits if their employment relationship does not seem to be stable (e.g. Davids and Gouws, 2013; van Oorschot and Halman, 2000).

Further, citizens' education levels affect their social welfare attitudes, although the results of previous studies are contradictory. Education increases social capital, which, according to the interest theory, could mean that the highly educated do not need the welfare state as much as the less educated. Thus, the attitudes of the highly educated towards the welfare state and social welfare may be more reserved than those of the less educated who have a vested interest in supporting social policy (cf. Valdimarsdóttir, 2010). On the other hand, according to path dependency theory (cf. Breznau, 2020), the meaning of education is related to societal
Study on public attitudes towards social benefits 
IJSSP

$41,13 / 14$

54

systems in a country. In a strong welfare state, the state invests in education, which, in turn, raises the support of public-funded education among the citizens. Also, if people support public-funded education it is likely that they also support other socio-political measures that are funded by the state (cf. Allmendinger and Leibfried, 2003; West and Nikolai, 2013). In this sense, a high education level is associated with those citizen's views on the government's social responsibility.

Political opinion is also a factor that explains citizens' attitudes towards social welfare. The political Left has traditionally emphasised the state's social responsibility and the state's role in social policy. Instead, the political Right underlines the importance of an individual's social responsibility. It is shown that when the political view goes from Right to Left, the support for social benefits and services goes up (Blekesaune, 2007; Pederson and Shekha, 2018; Roosma et al., 2014; van Oorcshot, 2006; Wulfgramm and Starke, 2017). It can be concluded that differences underlying political opinion are deep in the philosophical thinking of society and its cultural values.

\subsection{Immigration as a new explanatory factor of social welfare attitudes}

Many recent studies have shown that immigration is a new and significant factor explaining citizen's social welfare attitudes. While, as aforementioned, Burgoon and Rooduijin (2021) write on the "Immigrationization of welfare policy", Schmidt-Catran and Spies (2016) showed that native citizens have negative attitudes towards social welfare programmes when the immigration rate is high. Garand et al. (2017) found a strong connection between attitudes towards immigration and attitudes towards welfare redistribution.

Furthermore, Kulin et al. (2016) argue that the majority of Europeans do not support both social welfare and immigration. Avdagic and Savage (2019) found that negative information on immigration weakens citizens' support for social welfare with an impact that is strong and pervasive. Concannon and Elsner (2020) showed that immigration has a negative effect on the support for redistribution, taxation and spending. Also, an insecure life situation affects the results: the more adverse the economic situation is, the more negative the attitude towards immigration becomes (Avdagic and Savage, 2019). Eger and Bohman (2016) found evidence that immigration attitude is associated with political ideology.

However, there are studies that argue contrariwise and Crepaz and Damron (2009) found evidence for a positive connection between comprehensive welfare state and tolerance towards immigrants. Meanwhile, Eger and Breznau (2017) remind us that we should not combine welfare state attitudes and welfare state nationalism because they are different phenomena. Auspurg et al. (2019) claim that the rate of immigration does not influence welfare state support, instead there is the association of immigration and social welfare support moderated by economic hardship (in terms of high unemployment rates). Whereas, Schmidt-Catran and Spies (2019) showed that native-born populations become more reluctant to support welfare programmes when the proportion of foreigners at the regional level increases. This effect is particularly strong in the initial phase of immigration, and it is further moderated by the economic context: the higher the unemployment rate is, the more negative the effect of foreigners on natives' attitudes towards providing welfare becomes. Those authors used the same basic data as Auspurg et al. (2019) but in a longitudinal form and also in regional contexts.

Attitudes towards immigration within a social political context may be explained by interest theory, which assumes that people's reactions to immigration are based on their own self-interests. In that, a citizen's attitude is negative if his/her societal position is insecure, and vice versa. On the other hand, the immigration issue may be approached from cultural and value perspectives, which emphasise the narratives that are attached to the issue. 
According to Kymlicka and Banting (2006), multiculturalism is likely to sustain, rather than erode, national solidarity when it is integrated into a national narrative that is a source of collective pride. When it takes place, the effects of heterogeneity are unlikely to be corrosive in the context of the welfare state.

\section{Research question, data and methodology}

\subsection{Hypothesis}

As aforementioned, we focus on the Nordic countries, which are the classic representatives of universal social policy. In these countries (Finland, Norway and Sweden), the welfare state has a strong public support. On the other hand, immigration is a social issue which seems to divide citizens' opinions, and also may challenge citizens' traditional support on socio-political universalism; that is, discerning between the deserving and the undeserving (Mackenzie and Louth, 2020). With this rationale, we study the effect of immigration on citizens' social welfare attitudes. We hypothesise (Hypothesis 1) that citizens' opinions of the immigration issue are associated with their attitudes towards social welfare. We also hypothesise (Hypothesis 2) that the attitudinal effect of the immigration issue on social welfare attitudes depends on socioeconomic factors, such as education level, political opinion and income level.

\subsection{Data}

The data were retrieved from the eighth round of European Social Survey's (ESS, 2014). The data were gathered in 2016, and they include 23 countries (44,387 respondents). The survey involves strict random probability sampling, a minimum target response rate of $70 \%$ and rigorous translation protocols. The hour-long face-to-face interview includes questions on a variety of core topics that are repeated from previous rounds of the survey, and two modules developed for Round 8 including social welfare attitude. For this study, we gathered the data from the following countries: Finland, Norway and Sweden (raw data, $N=5,021)$. The data were weighted following the recommendations of the ESS (2014), which means that the number of respondents in each Nordic country are adjusted to the size of the country. The number of respondents in the weighted data for the Nordic countries (Finland, Norway and Sweden) was 1,770.

This study has a focus on social welfare attitude which was operationalised through four questions on social benefits and services. The dependent variable consists of the following four items: "Social benefits and services in [country] place too great a strain on the economy?" (Question E9), "Social benefits and services in [country] cost businesses too much in taxes and charges?" (Question E12), "Social benefits and services in [country] make people lazy?" (Question E13) and "Social benefits and services in [country] make people less willing to care for one another?" (Question E14). The scales of those four variables go negative to positive using the scale from 1 to 5 . Cronbach's alpha for the sum variable was 0.722 . Table 1 shows the distribution of the dependent variable for the entire data and the groups of three countries. The mean over the entire data is 3.02 (Standard Deviation $=0.766$ ) (Table 4). There were some differences between the countries in the mean of attitudes towards social benefits and services: Finland 3.03 $($ Standard Deviation $=0.733)$, Norway $2.99($ Standard Deviation $=0.729)$ and Sweden 3.03 (Standard Deviation $=0.780$ ).

Table 2 shows the distribution of the independent variables: age, gender, education level, income level and political opinion (which is operationalised into political placement). The selection of the independent variables was based on the previous studies. The means of the independent variables are presented in Table 4.

Immigration attitude was operationalised by creating a sum variable from two items (Table 3): "Would you say that [country]'s cultural life is generally undermined or
Study on public attitudes towards social benefits 
IJSSP

$41,13 / 14$

56

Finland

$5=$ positive

Sweden

\begin{tabular}{|c|c|c|c|}
\hline & Categories & $N$ & $\%$ \\
\hline \multirow[t]{5}{*}{ Entire Data } & $1=$ negative & 34 & 2.0 \\
\hline & 2 & 300 & 17.7 \\
\hline & 3 & 802 & 47.4 \\
\hline & 4 & 499 & 29.5 \\
\hline & $5=$ positive & 57 & 3.4 \\
\hline \multirow[t]{5}{*}{ Finland } & 1 & 8 & 1.8 \\
\hline & 2 & 89 & 19.4 \\
\hline & 3 & 198 & 43.3 \\
\hline & 4 & 148 & 32.4 \\
\hline & 5 & 14 & 3.1 \\
\hline \multirow[t]{5}{*}{ Sweden } & 1 & 17 & 2.1 \\
\hline & 2 & 138 & 17.2 \\
\hline & 3 & 385 & 47.8 \\
\hline & 4 & 233 & 28.9 \\
\hline & 5 & 32 & 4.0 \\
\hline \multirow[t]{5}{*}{ Norway } & 1 & 7 & 1.8 \\
\hline & 2 & 73 & 17.1 \\
\hline & 3 & 218 & 51.1 \\
\hline & 4 & 117 & 27.5 \\
\hline & 5 & 11 & 2.5 \\
\hline
\end{tabular}

Table 1.

Norway

Dependent variable

(frequency

distribution,

weighted data)

\begin{tabular}{llrr}
\hline & Categories & $N$ & $\%$ \\
\hline \multirow{2}{*}{ Age } & Under 35 & 520 & 30.5 \\
& $35-60$ & 688 & 40.5 \\
Gender & Above 60 & 492 & 29.0 \\
& Men & 850 & 50.0 \\
Education level & Women & 850 & 50.0 \\
& Less than secondary level & 148 & 8.7 \\
Political placement & Secondary level & 836 & 49.4 \\
& Higher than secondary level & 709 & 41.7 \\
& $0=$ Left & 46 & 2.8 \\
& 1 & 29 & 1.8 \\
& 2 & 79 & 4.8 \\
& 3 & 191 & 11.7 \\
& 4 & 175 & 10.7 \\
& 5 & 407 & 25.0 \\
& 6 & 177 & 10.9 \\
Income level & 7 & 248 & 15.2 \\
& 8 & 181 & 11.1 \\
& 9 & 43 & 2.6 \\
& 10 & 55 & 3.4 \\
& 1. decile & 137 & 8.7 \\
& 2. decile & 136 & 8.6 \\
& 3. decile & 140 & 8.8 \\
& 4. decile & 146 & 9.2 \\
& 5. decile & 161 & 10.1 \\
& 6. decile & 156 & 9.9 \\
& 7. decile & 165 & 10.4 \\
& 8. decile & 188 & 11.9 \\
& 9. decile & 178 & 11.3 \\
& 10. decile & 177 & 11.2 \\
& 1,700 & 100.0 \\
& & &
\end{tabular}

Table 2.

Independent variables (frequency distribution)

Total 


\begin{tabular}{|c|c|c|c|c|}
\hline & Categories & $N$ & $\%$ & Study on public \\
\hline \multirow[t]{11}{*}{ Entire Data } & $0=$ negative & 9 & 0.6 & towards social \\
\hline & 1 & 23 & 1.4 & henefits \\
\hline & 2 & 36 & 2.1 & benefits \\
\hline & 3 & 70 & 4.2 & \\
\hline & 4 & 120 & 7.2 & \\
\hline & 5 & 234 & 14.1 & 57 \\
\hline & 6 & 300 & 18.0 & \\
\hline & 7 & 316 & 19.0 & \\
\hline & 8 & 298 & 17.9 & \\
\hline & 9 & 158 & 9.5 & \\
\hline & $10=$ positive & 100 & 6.0 & \\
\hline \multirow[t]{11}{*}{ Finland } & 0 & 3 & 0.6 & \\
\hline & 1 & 4 & 1.1 & \\
\hline & 2 & 9 & 1.8 & \\
\hline & 3 & 16 & 3.6 & \\
\hline & 4 & 34 & 7.5 & \\
\hline & 5 & 58 & 12.8 & \\
\hline & 6 & 89 & 19.7 & \\
\hline & 7 & 98 & 21.6 & \\
\hline & 8 & 85 & 18.7 & \\
\hline & 9 & 41 & 9.0 & \\
\hline & 10 & 16 & 3.6 & \\
\hline \multirow[t]{11}{*}{ Sweden } & 0 & 2 & 0.3 & \\
\hline & 1 & 12 & 1.4 & \\
\hline & 2 & 16 & 2.1 & \\
\hline & 3 & 32 & 4.0 & \\
\hline & 4 & 43 & 5.5 & \\
\hline & 5 & 92 & 11.7 & \\
\hline & 6 & 131 & 16.5 & \\
\hline & 7 & 146 & 18.4 & \\
\hline & 8 & 153 & 19.3 & \\
\hline & 9 & 92 & 11.7 & \\
\hline & 10 & 73 & 9.2 & \\
\hline \multirow[t]{11}{*}{ Norway } & 0 & 4 & 1.0 & \\
\hline & 1 & 7 & 1.7 & \\
\hline & 2 & 11 & 2.6 & \\
\hline & 3 & 22 & 5.3 & \\
\hline & 4 & 43 & 10.2 & \\
\hline & 5 & 83 & 19.8 & \\
\hline & 6 & 80 & 19.1 & \\
\hline & 7 & 72 & 17.2 & The variable of \\
\hline & 8 & 61 & 14.5 & immigration attitude \\
\hline & 9 & 25 & 6.0 & (frequency \\
\hline & 10 & 11 & 2.5 & distribution) \\
\hline
\end{tabular}

enriched by people coming to live here from other countries?" (Question B42) and "Is [country] made a worse or a better place to live by people coming to live here from other countries?" (Question B43). The scale of the variables was from 0 to 10. Cronbach's alpha of the sum variable was 0.722. The mean of the variable was 6.25 (Standard Deviation $=2.046$ ) in the group of all countries (Table 4 ). There were some differences between the countries in the mean of immigration attitude: Finland 6.23 (Standard Deviation $=1.905$ ), Norway 5.71 (Standard Deviation $=1.99$ ) and Sweden 6.56 $($ Standard Deviation $=2.097)$. 
IJSSP

$41,13 / 14$

\section{8}

\subsection{Methodology}

We carried out the analysis as follows. We undertook the descriptive analysis by examining the normality and the mean of the dependent variable social welfare attitude both at the country-level and at the group-level of all three countries. We conducted the variance analysis (ANOVA) for the dependent variable social welfare attitude and the independent variables between countries and on the entire data set (one-sample $t$-test). Also, we calculated the Spearman's correlation coefficients between social welfare attitude and the independent variables.

The main analysis was performed using linear regression analysis (the "enter" method). A review of the assumptions for regression analysis found that there is no interfering multicollinearity between the variables. The values of variance inflation factor were less than 1.2. The linear relationship between the response variable and the explanatory variables was examined using a residual pattern that showed no violations, and residuals were normally distributed. However, the Breusch and Pagan test describing the uniformity of variance of residual terms did not yield an acceptable result. The linear regression analysis utilises the list wise method, which causes problems in a situation of missing information. The share of missing values for the dependent variable was $0.65 \%$, and in the case of the independent variables was between 0.06 and $7.2 \%$ (see Table 4). According to Little's Missing Completely at Random (Little 1988) test, the data was observed to be missing completely at random (Chi-Square $=16.852$, Degrees of freedom $(\mathrm{DF})=22$, Sig. $=0.771)$. All descriptive and linear regression analyses were made in the Statistical Package for the Social Sciences (SPSS) 27 programme. The graph of the interaction term was figured by using the PROCESS programme and was edited using Microsoft Excel.

\section{Results}

\subsection{Descriptive analyses}

According to the descriptive analysis, there was no difference between men and women regarding their attitudes towards social benefits and services (Table 5). Age and income level were not statistically significant; hence, those factors did not correlate with the dependent variable. Whereas, education level, political placement and immigration attitude were statistically significant. Political placement was in a negative relationship with the dependent variable, whereas education level and income level were in a positive relationship with the dependent variable. The more Left-wing the respondent was with his/her political placement, the more positive the attitude she/he had towards social benefits and services. For simplifying the interpretation of education level, we coded it also into three categories. The respondents with higher than secondary school education seem to support social benefits and services more than the lower education respondents. However, the difference is negligible.

\begin{tabular}{lrcc}
\hline & $N$ (missing) & Mean & Standard deviation \\
\hline Social welfare attitude & $1,690(11)$ & 3.02 & 0.766 \\
Gender & $1,700(1)$ & 0.5 & 0.500 \\
Age & $1,698(2)$ & 47.59 & 19.536 \\
Income level & $1,585(115)$ & 5.8 & 2.854 \\
Education level & $1,698(2)$ & 4.26 & 3.298 \\
Political placement & $1,698(2)$ & 5.32 & 2.209 \\
Immigration attitude & $1,666(35)$ & 6.25 & 2.046 \\
Total & 1,700 & &
\end{tabular}

$$
\text { negle. }
$$

\section{Table 4.}

Dependent variable and independent variables (number of cases, mean, standard deviation) 


\begin{tabular}{|c|c|c|c|c|c|}
\hline & \multicolumn{4}{|c|}{ The dependent variable: Social benefits and services } & \multirow{2}{*}{$\begin{array}{r}\text { Study on public } \\
\text { attitudes }\end{array}$} \\
\hline & $N$ & Mean & Standard deviation & $F$ & \\
\hline Total & 1,690 & 3.02 (p) & 0.766 & \multirow{3}{*}{$\begin{array}{c}- \\
\mathrm{F}_{1,1,687}=6.458\end{array}$} & \multirow{2}{*}{$\begin{array}{r}\text { towards social } \\
\text { benefits }\end{array}$} \\
\hline ender, man & 846 & 2.97 & 0.765 & & \\
\hline Gender, woman & 844 & 3.07 & 0.764 & & \\
\hline Age & 663 & $-0.020(\mathrm{~S})$ & 0.604 & \multirow[t]{2}{*}{ - } & \\
\hline Education level & 665 & 0.227 & $0.000(\mathrm{p})$ & & \\
\hline Education, lower than secondary & 146 & 2.75 & 0.779 & $\mathrm{~F}_{2,1,680}=19.994(\mathrm{p})$ & \\
\hline Education, secondary & 830 & 2.97 & 0.714 & & \multirow{5}{*}{$\begin{array}{l}\text { Table } 5 . \\
\text { Associations between } \\
\text { the dependent variable } \\
\text { and the independent } \\
\text { variables (one-sample }\end{array}$} \\
\hline Education, higher than secondary & 708 & 3.14 & 0.799 & & \\
\hline Income level & 609 & 0.054 & 0.179 & - & \\
\hline Political placement & 637 & $-0.387(\mathrm{~S})$ & $0.000(\mathrm{p})$ & - & \\
\hline Immigration attitude & 650 & 0.340 (S) & $0.000(\mathrm{p})$ & - & \\
\hline \multicolumn{5}{|c|}{$\begin{array}{l}\text { Note(s): } \mathrm{S}=\text { Spearman correlation; } \mathrm{p}=\text { sig. ( } 0.001 \text { is significant) } \\
\text { One-Sample } t \text {-Test: Total; One-way ANOVA: gender, education; Spearman correlation: age, education, income, } \\
\text { political ideology, immigration attitude }\end{array}$} & $\begin{array}{r}t \text {-test, one-way } \\
\text { ANOVA and } \\
\text { Spearman correlation) }\end{array}$ \\
\hline
\end{tabular}

\subsection{Effect of immigration issue}

The results of the linear regression analysis are presented in Table 6. The non-standardised and standardised $\beta$ coefficients are presented in the table; hence, the explanatory variables can be viewed as independent as well as being compared with each other. The explanatory factors were added in five phases: Model 1 (age and gender), Model 2 (the socio-economic factors were added into the previous model), Model 3 (immigration attitude was added into the previous model), Model 4 (the interaction terms of the socio-economic factors were added into the previous model) and Model 5 (the interaction terms of immigration and the socio-economic factors were added into the previous model). Model 3 explains $17.3 \%$ of the variance of the dependent variable and the last model (Model 5) with interaction terms $18.5 \%$ of the variance. The three-ways Interactions were also tested in the analysis, but not reported because they were not statistically significant.

Gender was a statistically significant factor in Model 1, but it was displaced by the socio-economic factors (political placement, education level and income level) in Model 2. Age was not a statistically significant factor in either of the models. Political placement $(\phi<0.001)$ and education level $(\phi<0.01)$ were statistically significant factors. The value of political placement was negative: the more Left-wing a respondent was, the more of a positive attitude she/he had towards social benefits and services. Whereas, when the value of education level was positive: the more educated a respondent was and the more positive attitude she/he had towards social benefits and services. Also, income level $(\phi<0.05)$ was positively associated with attitude towards social benefits and services. However, the effect of income level was no longer statistically significant when immigration attitude was added into the model (Model 3). Immigration attitude $(p<0.001)$ was positively associated with attitude towards social benefits and services. According to the standardised coefficients, political placement $\left(\beta=-0.294^{* * *}\right)$ and immigration attitude $\left(\beta=0.232^{* * *}\right)$ had the biggest effects on attitude towards social benefits and services. Hence, Hypothesis (H1) was supported because attitude towards the immigration issue was associated with attitude towards social welfare.

In Model 4, the interaction terms of the socio-economic factors were added into the analysis, from which only the interaction term of education level and political placement was statistically significant $(\phi<0.001)$. In Model 5 , the immigration attitude $\left(\beta=0.370^{* * *}\right)$ was the only statistically significant factor of all the individual variables. In this model, the interaction terms of immigration and the socio-economic factors were added into the analysis, of which only the interaction term of immigration attitude and political placement was 
IJSSP

41,13/14

60

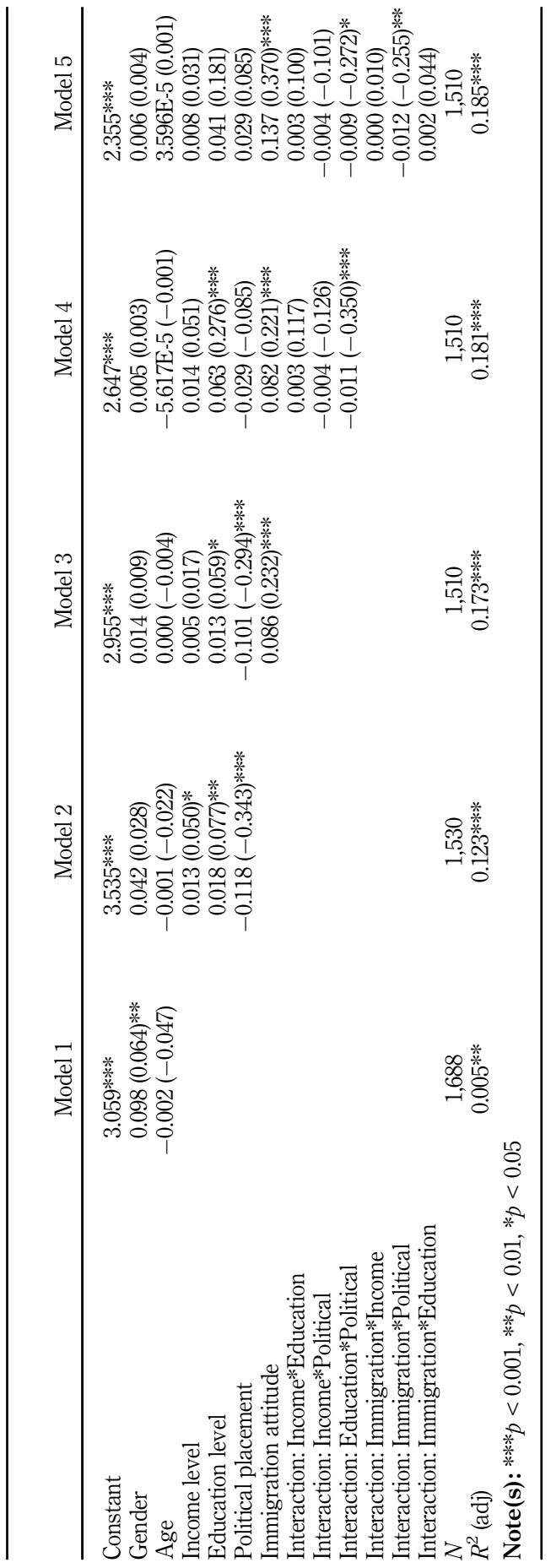

Table 6.

Linear regression analysis (nonstandardised $\beta$ values, standardised values in parentheses) 
statistically significant (standardised $\beta=-0.255^{* *}$ ). The interaction term is statistically significant also when tested separately in each country (Finland, Norway and Sweden, respectively), although these analyses are not reported. In this sense, Hypothesis (H2) was partially supported, because the attitudinal effect of the immigration issue on social welfare depended only on political opinion. In addition, the interaction term of education level and political placement was still statistically significant $\left(\beta=-0.272^{*}\right)$ in Model 5 .

\subsection{Visualising the interaction between immigration attitude and political placement}

The effect of the interaction term between immigration attitude and political placement can also be visualised, which makes it clearer what is happening in the data. According to Figure 1, immigration attitude and attitude towards social benefits and services is positively associated. The more positive the immigration attitude is, the more positive the attitude towards social benefits and services becomes. Furthermore, attitude towards social benefits and services is more positive among the supporters of the political Left than the people who place themselves as Right-wing. But the slope linking the immigration issue with attitude towards social benefits and services is steeper among those who are in the political Left. In this sense, the difference between positive and negative immigration attitudes is wider in the political Left than in the political Right. The Right-wing people's opinions on social benefits and services seem to be more coherent, so that change in the view of the immigration issue does not affect their view on social benefits and services as much as it affects on the views of Left-wing people.

\section{Discussion}

The starting point of this study was to examine whether attitude towards social welfare (operationalised into social benefits and services) and immigration attitude are associated in the Nordic countries, and whether the attitudinal effect of immigration issue on social welfare attitude depends on the socio-economic factors, such as education level, income level and political opinion (operationalised into political placement). According to the results of this study, we wish to raise and include three issues into the theoretical discussion.

First, the immigration issue divides citizens' opinions, and it seems also to be associated with their attitudes towards social welfare. The view is the same in all three Nordic countries

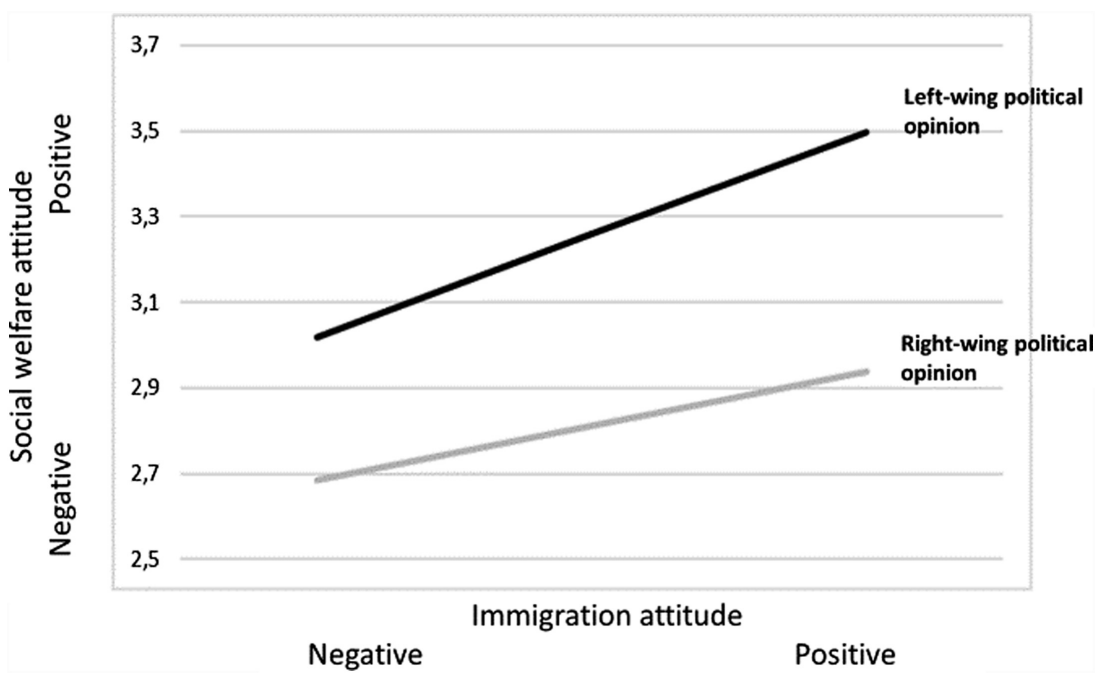

Study on public attitudes towards social benefits

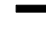


IJSSP

$41,13 / 14$

that are involved in this study: Finland, Norway and Sweden. A person who does not support immigration also has a more negative attitude towards social welfare compared to those who support immigration. In this sense, the immigration issue seems to be a key factor for understanding the mechanism of citizens' support of the welfare state. The same result is widely reported in the previous studies (i.e. Burgoon and Rooduijin, 2021; Concannon and Elsner, 2020; Garand et al., 2017). For instance, Schmidt-Catran and Spies (2016) remark more specifically that citizens become more reluctant to support social welfare when the proportion of immigrants increases (cf. Auspurg et al., 2019). This effect is particularly strong in the initial phase of immigration. On the other hand, Kulin et al. (2016) demonstrate that within the three countries of this study there are different clusters of opinions, in which people have a negative or positive attitude towards immigration and social welfare, but additionally they found a cluster where people had a positive attitude towards social welfare but a negative attitude towards immigration.

Second, our main focus was on the interaction of the immigration issue and the socio-economic factors. We found that of all the socio-economic factors only political opinion and immigration attitude interacted together and affected attitudes towards social welfare (Figure 1). We found that the effect of immigration attitude on social welfare attitudes appears to be stronger among those who had Left-wing political views compared to those who had Right-wing political views. On the other hand, the difference between the effects of positive and negative immigration attitudes on social welfare attitudes was wider in the political Left than in the political Right. To the best of our knowledge, the interaction between the immigration factor and political opinions has not been reported in the previous studies.

It seems that the immigration issue might even be a kind of prism which divides the views of the political Left on social welfare. The Right-winger views on social welfare seem to be more coherent, so that the views on immigration do not affect their views on social welfare as much as on the views of the Left-winger views. In this sense, our result might compliment the evidence of Kulin et al. (2016) who showed that there is a division for positive and negative views on immigration within the group with a positive social welfare attitude. A part of those who support social welfare do not support the immigration issue. They claim that the group has a "pro welfare and anti-immigration" attitude, which in their own words is a challenge for progressive political parties. Our study found evidence that the challenge is especially focused on the political Left, which typically has been supporting social policy measures. The whole system of the Nordic welfare state is based on the ideas of social democracy (Esping-Andersen, 1990) which indeed is not only owned by the Left-wingers; however, the idea of universalism is more symbolic for the Left-wingers.

Third, the question of socio-economic factors is a complex. We found that income level did not affect people's support of social welfare, contrary to the previous studies (Davids and Gouws, 2013; van Oorschot and Halman, 2000). However, political opinion and education level were statistically significant before the interaction terms were included in the analysis. The more Left-leaning the people are, the more they support the welfare state (van Oorcshot, 2006; Wulfgramm and Starke, 2017). Also, it was found that citizens' attitudes towards social welfare was more reserved if they were less educated (cf. Valdimarsdóttir, 2010). Political opinion and education level were statistically significant in the model before the interaction term of immigration attitude and political placement was included into the analysis; however, in this final model, the interaction term of political opinion and education level appeared to be statistically significant.

In general, our study found evidence for the significance of the immigration issue on citizens' opinion on social welfare. However, there are also some limitations regarding this study. First, this study is focused on Finland, Norway and Sweden, which are traditional Nordic welfare states; but, the Nordic welfare state is not a coherent entity. There are also differences between the social political systems of each of the three countries. Second, there 
are also differences regarding the factual rates of immigration in these countries. Sweden has the largest population of immigrants compared to Finland and Norway. The factual immigration rate has been found to be a significant factor for citizens' opinions on social welfare (Schmidt-Catran and Spies, 2016). Third, citizens' opinions are not unambiguous issues. They have different attitudes towards the different dimensions of social welfare. People are positive about some of these dimensions, and they are more critical of other dimensions (Roosma et al., 2014; Zaller, 1992). In this sense, we underline that our results are tentative and further research is needed in the future for verifying these results.

\section{Conclusions}

According to this study, the Nordic welfare state and its social security system is strongly supported among citizens in three countries, that is, Finland, Norway and Sweden. However, the immigration issue seems to be a significant attitudinal factor which affects citizens' opinions on social welfare. We found that the immigration issue affects citizens' attitudes towards social welfare and the social security system in the Nordic countries. People who have negative attitudes towards immigration also have negative attitudes towards social welfare. The result is consistent with the broad bulk of recent studies (e.g. Burgoon and Rooduijn, 2021; Schmidt-Catran and Spies, 2016; Eger and Breznau, 2017).

Further, our main result was that the immigration issue is associated with political opinion so that its effect divides the supporters of the political Left more than the political Right. This gives us an interesting perspective of the legitimacy of social policy in the Nordic countries, because the Nordic welfare state has been thought to be, above all, a product of socio-democratic ideology, although, of course, universal social policy had also been adopted by the Right-wing parties during the time when the welfare state was built (Anttonen and Sipilä, 2012; Korpi, 1983). The result is inconsistent with the traditional theory of social policy (Korpi, 1983), as the welfare state has generally received strong support, and especially from the Left. According to that study, it seems that a part of the Left views immigration negatively, which also reduces their confidence in the principle of universalism.

Although our study cannot reveal the rationale behind the mechanism of citizens' support for the welfare state, we can assume that the so-called deservingness theory might be a potential theoretical direction to be considering for further research. According to deservingness theory, citizens use different criteria to rate the deservingness of different groups of welfare recipients. Immigrants may be seen as less deserving of social benefits and services compared to the native population (van Oorschot, 2000). Furthermore, the rationale behind the mechanism of citizens' support for the social welfare state may refer to the welfare magnet hypothesis, which assumes that especially the tax-financed welfare states are attractive for immigrants because of their universal social benefits and services, and because of this, the native citizens' confidence in the welfare state may be reduced (Martinsen and Werner, 2019). The studies on "welfare chauvinism" have also focused on the similar situation (Eick and Larsen, 2021), but further research is needed before we can address the issue in a more detailed way.

In this sense, the current Nordic welfare state model is challenged, not only from the perspective of the new Right-wing and neoliberalism (Kamali and Jönsson, 2018), but also from the perspective of immigration (Scarpa and Schierup, 2018). In that, the transition in public opinion can even change the future welfare state structures and their functions. However, it is noteworthy that changes in the social policy system are slow and thus require considerably long period of time before they can actually be verified. In this sense, we underline that the issue of immigration seems to be one of the key factors shaping the attitudinal basis of social policy (cf. Meinander, 2021), but we cannot be certain regarding whether or not this effect is long term and whether or not it will cause factual changes in the social security system.
Study on public attitudes towards social benefits 
IJSSP

$41,13 / 14$

\section{Note}

1. The immigration crises in 2015 had an effect on discussions on social welfare at the national level (Eger et al., 2020). At the time of the immigration crises in 2015, Sweden received relatively the majority of refugees in Europe, $1.60 \%$ of its population. Finland and Norway both received refugees amounting to $0.58 \%$ of their population, which is at the same level as Germany, which received refugees amounting to $0.54 \%$ of its population.

\section{4}

\section{References}

Allmendinger, J. and Leibfried, S. (2003), "Education and the welfare state: the four worlds of competence production”, Journal of European Social Policy, Vol. 13 No. 1, pp. 63-81.

Anttonen, A. and Sipilä, J. (2012), "Universalism in the British and Scandinavian social policy debates", in Anttonen, A. (Ed.), Welfare State, Universalism and Diversity, Edward Elgar Publishing, Cheltenham, pp. 16-41.

Auspurg, K., Brüderl, J. and Wöhler, T. (2019), "Does immigration reduce the support for welfare spending? A cautionary tale on spatial panel data analysis", American Sociological Review, Vol. 84 No. 4, pp. 754-763.

Avdagic, S. and Savage, L. (2019), "Negativity bias: the impact of framing of immigration on welfare state support in Germany, Sweden and the UK", British Journal of Political Science, Vol. 51 No. 2, pp. 624-645.

Blekesaune, M. (2007), "Economic conditions and public attitudes to welfare policies", European Sociological Review, Vol. 23 No. 3, pp. 393-403.

Blekesaune, M. and Quadagno, J. (2003), "Public attitudes toward welfare state policies: a comparative analysis of 24 nations", European Sociological Review, Vol. 19 No. 5, pp. 415-427.

Breznau, N. (2018), "Anti-immigrant parties and Western European society: analyzing the role of immigration and forecasting voting", OSF Preprints, doi: 10.31219/osf.io/pge9j.

Breznau, N. (2020), "Bi-directional feedback to the welfare state and public opinion”, SocArXiv. doi: 10. 31235/osf.io/h8aqe.

Burgoon, B. and Rooduijn, M. (2021), “Immigrationization' of welfare politics? Anti-immigration and welfare attitudes in context", West European Politics, Vol. 44 No. 2, pp. 177-203.

Cantante, F. (2020), "Four profiles of inequality and tax redistribution in Europe", Humanities and Social Sciences Communications, Vol. 7 No. 1, pp. 1-7.

Concannon, J. and Elsner, B. (2020), Immigration and Redistribution, Working Paper Series WP20/24, University College Dublin, UCD Centre for Economic Research, Dublin.

Crepaz, M.M. and Damron, R. (2009), "Constructing tolerance: how the welfare state shapes attitudes about immigrants", Comparative Political Studies, Vol. 42 No. 3, pp. 437-463.

Davids, Y.D. and Gouws, A. (2013), "Monitoring perceptions of the causes of poverty in South Africa", Social Indicators Research, Vol. 110 No. 3, pp. 1201-1220.

Diermeier, M., Niehues, J. and Reinecke, J. (2020), "Contradictory welfare conditioning-differing welfare support for natives versus immigrants", Review of International Political Economy, pp. 1-28, doi: 10.1080/09692290.2020.1780294, Published Online: 06 Jul 2020.

Eger, M.A. and Bohman, A. (2016), "The political consequences of contemporary immigration", Sociology Compass, Vol. 10 No. 10, pp. 877-892.

Eger, M.A. and Breznau, N. (2017), "Immigration and the welfare state: a cross-regional analysis of European welfare attitudes", International Journal of Comparative Sociology, Vol. 58 No. 5, pp. 440-463.

Eger, M.A., Larsen, C.A. and Mewes, J. (2020), "Welfare nationalism before and after the 'migration crisis", in Laenen, T., Meuleman, B. and van Oorschot, W. (Eds), Welfare State Legitimacy in Times of Crisis and Austerity: between Change and Continuity, Edward Elgar Publishing, London, pp. 177-198.

Eick, G.M. and Larsen, C.A. (2021), "Welfare chauvinism across benefits and services", Journal of European Social Policy, 09589287211023047. 
Ellingsæter, A.L., Kitterød, R.H. and Lyngstad, J. (2017), "Universalising childcare, changing mothers' attitudes: policy feedback in Norway", Journal of Social Policy, Vol. 46 No. 1, pp. 149-173.

Ervasti, H. (2001), "Class, individualism and the Finnish welfare state", Journal of European Social Policy, Vol. 11 No. 1, pp. 9-23.

Ervasti, H. (2012), "Who hates the welfare state? Criticism of the welfare state in Europe", in Ervasti, H., Andersen, J.G., Fridberg, T. and Ringdal, T. (Eds), The Future of the Welfare State. Social Policy Attitudes and Social Capital in Europe, Edward Elgar, Cheltenham, pp. 231-248.

Esping-Andersen, G. (1990), The Three Worlds of Welfare Capitalism, Princeton University Press, Princeton, NJ.

European Social Survey (ESS) (2014), "Weighting European social survey data”, available at: http:// www.europeansocialsurvey.org/ (accessed 15 January 2015).

Fernández, J. and Jaime-Castillo, A.M. (2018), "The institutional foundation of social class differences in pro-redistribution attitudes. A cross-national analysis, 1985-2010”, Social Forces, Vol. 96 No. 3, pp. 1009-1038.

Garand, J.C., Xu, P. and Davis, B.C. (2017), "Immigration attitudes and support for the welfare state in the American mass public", American Journal of Political Science, Vol. 61 No. 1, pp. 146-162.

Gugushvili, D., Ravazzini, L., Ochsner, M., Lukac, M., Lelkes, O., Fink, M., Grand, P. and van Oorschot, W. (2021), "Welfare solidarities in the age of mass migration: evidence from European Social Survey 2016", Acta Politica, Vol. 56 No. 2, pp. 1-25.

Kamali, M. and Jönsson, J.H. (2018), Neoliberalism and the Transformation of Social policy Neoliberalism, Nordic Welfare States and Social Work: Current and Future Challenges, Routledge, London.

Kim, H. and Yushin, L. (2018), "Socioeconomic status, perceived inequality of opportunity, and attitudes towards redistribution", The Social Science Journal, Vol. 55 No. 3, pp. 300-312.

Korpi, W. (1983), The Democratic Class Struggle, Routledge \& Kegan Paul, London.

Kulin, J., Eger, M.A. and Hjerm, M. (2016), "Immigration or welfare? The progressive's dilemma revisited”, Socius: Sociological Research for a Dynamic World, Vol. 2, 2378023116632223.

Kumlin, S. and Stadelmann-Steffen, I. (2014), "Citizens, policy, and European welfare states", in Kumlin, S. and Stadelmann-Steffen, I. (Eds), How Welfare States Shape the Democratic Public. Policy Feedback, Participation, Voting, and Attitudes, Edgard Elgar, Cheltenham, pp. 3-17.

Kymlicka, W. and Banting, K. (2006), "Immigration, multiculturalism, and the welfare state", Ethics and International Affairs, Vol. 20 No. 3, pp. 281-304.

Larsen, C.A. (2008), "The institutional logic of welfare attitudes", Comparative Political Studies, Vol. 41 No. 2, pp. 145-168.

Little, R.J. (1988), “A test of missing completely at random for multivariate data with missing values", Journal of the American statistical Association, Vol. 83 No. 404, pp. 1198-1202.

Mackenzie, C. and Louth, J. (2020), "The neoliberal production of deserving and undeserving poor: a critique of the Australian experience of microfinance", Social Policy and Society, Vol. 19 No. 1, pp. 19-35.

Martinsen, D.S. and Werner, B. (2019), "No welfare magnets-free movement and cross-border welfare in Germany and Denmark compared", Journal of European Public Policy, Vol. 26 No. 5, pp. 637-655.

Meinander, H. (2021), "Three driving forces: structural challenges for Nordic democracies in the 2010s", in Koivunen, A., Ojala, J. and Holmen, J. (Eds), The Nordic Economic, Social and Political Model, Routledge, London, pp. 20-36.

Nygård, M. (2006), "Welfare-ideological change in Scandinavia: a comparative analysis of partisan welfare state positions in four Nordic countries, 1970-2003”, Scandinavian Political Studies, Vol. 29 No. 4, pp. 356-385.

Pederson, J. El. and Shekha, K.R. (2018), "Attitudes toward public pensions in Chile, Uruguay, and Venezuela. Testing self-interest and political ideology theories in Latin American countries", International Social Work, Vol. 61 No. 2, pp. 183-198.
Study on public attitudes towards social benefits 
IJSSP $41,13 / 14$

Pierson, P. (2001), "Coping with permanent austerity: welfare state restructuring in affluent democracies", in Leibfried, S. and Mau, S. (Eds), Welfare States: Construction, Deconstruction, Reconstruction, Edward Elgar, Cheltenham, pp. 276-328.

Rantanen, T., McLaughlin, T.C. and Toikko, T. (2015), "Do Finnish young people support the Nordic welfare state?", International Journal of Sociology and Social Policy.

Roosma, F., van Oorschot, W. and Gelissen, J. (2013), "The multidimensionality of welfare state attitudes: a European cross-national study”, Social Indicators Research, Vol. 113 No. 1, pp. 235-255.

Roosma, F., van Oorschot, W. and Gelissen, J. (2014), "The preferred role and perceived performance of the welfare state: European welfare attitudes from a multidimensional perspective", Social Science Research, Vol. 44, pp. 200-210.

Scarpa, S. and Schierup, C.U. (2018), "Who undermines the welfare state? Austerity-dogmatism and the U-turn in Swedish asylum policy”, Social Inclusion, Vol. 6 No. 1, pp. 199-207.

Schmidt-Catran, A.W. and Spies, D.C. (2016), "Immigration and welfare support in Germany", American Sociological Review, Vol. 81 No. 2, pp. 242-261.

Schmidt-Catran, A.W. and Spies, D.C. (2019), "Immigration and welfare support in Germany: methodological reevaluations and substantive conclusions", American Sociological Review, Vol. 84 No. 4, pp. $764-768$.

Svallfors, S. (2011), "A bedrock of support? Trends in welfare state attitudes in Sweden, 1981-2010", Social Policy and Administration, Vol. 45 No. 7, pp. 806-825.

Toikko, T., Seppälä, P., Kraav, S.L. and Häkkilä, L. (2021), "Kuntatason analyysi lastensuojelun avohuollon yhteydestä lastensuojeluilmoitusten ja sijoitusten väliseen suhteeseen”.

Valdimarsdóttir, M. (2010), Welfare State Attitudes, Characteristics Associated with Individual Support for Governmental Redistribution, Reykjavík: Félagsvísindastofnun Háskóla Íslands.

van Oorcshot, W. (2006), "Making the difference in social Europe. Deservingness perceptions among citizens of European welfare states", Journal of European Social Policy, Vol. 16 No. 1, pp. 23-42.

van Oorschot, W. (2000), "Who should get what, and why? On deservingness criteria and the conditionality of solidarity among the public", Policy and Politics, Vol. 28 No. 1, pp. 33-48.

van Oorschot, W. and Halman, L. (2000), "Blame or fate, individual or social? An international comparison of popular explanations of poverty", European Societies, Vol. 2 No. 1, pp. 1-28.

West, A. and Nikolai, R. (2013), "Welfare regimes and education regimes: equality of opportunity and expenditure in the EU (and US)", Journal of Social Policy, Vol. 42 No. 3, pp. 469-493.

Wulfgramm, M. and Starke, P. (2017), "Divided by the market, divided by the state. Distribution, redistribution and welfare attitudes in 47 countries", Scandinavian Social Politics, Vol. 40 No. 1, pp. 1-27.

Zaller, J.R. (1992), The Nature and Origins of Mass Opinions, Cambridge University Press, Cambridge.

\section{Appendix}

The supplementary file is available online for this article.

\section{Corresponding author}

Timo Toikko can be contacted at: timo.toikko@uef.fi

For instructions on how to order reprints of this article, please visit our website:

www.emeraldgrouppublishing.com/licensing/reprints.htm

Or contact us for further details: permissions@emeraldinsight.com 